\title{
DETERMINAN PREDIKSI KRISIS PERBANKAN BERBASIS BANKING SECTOR FRAGILITY INDEX
}

\author{
Dian hamida ${ }^{1}$, Nurmala Ahmar ${ }^{2}$, dan Syahril Djaddang ${ }^{3}$ \\ ${ }^{1}$ (Program Studi Akuntansi, Fakultas Ekonomi /Universitas Pancasila, Jakarta) \\ ${ }^{2}$ (Sekolah Tinggi Ilmu Ekonomi /Perbanas, Surabaya) \\ ${ }^{3}$ (Magister Akuntansi /Universitas Pancasila, Jakarta) \\ E-mail:dheean16@gmail.com
}

\begin{abstract}
The unfavorable condition of the banking system has a major impact on the economy in Indonesia. The existence of monthly BSF (Banking Sector Fragility) index can be used to decide whether the national banking system is experiencing crisis at some point. This study aims to analyze how the effect of capital (CAR), profitability, liquidity, Gross Domestic Product (GDP), inflation and exchange rate against banking crisis based on Banking Sector Fragility Index listed in Indonesia Stock Exchange 2010-2014 period in Indonesia. Data analysis technique in this research is using statistical approach that is descriptive statistic analysis and logistic regression. The results showed that capital, Gross Domestic Product, inflation and exchange rate did not affect the banking crisis based on Banking Sector Fragility Index in Indonesia and profitability. Meanwhile liquidity had an effect on to banking crisis based on Banking Sector Fragility Index in Indonesia.
\end{abstract}

\section{Keywords: BSF Index, CAR, Profitability, Liquidity, GDP, Inflation, Exchange Rate}

\section{PENDAHULUAN}

Biro riset info bank (2015), melakukan kajian terhadap 118 bank berdasarkan laporan keuangan per Desember 2014 yang dipublikasikan. Hasilnya, 65 bank berpredikat sangat bagus. Hasil ini menunjukkan bahwa industri perbankan sebagai salah satu penggerak perekonomian di Indonesia masih jauh dari target yang diharapkan dan tantangan berat pun masih terus menghadang industri perbankan di Indonesia. Dari 118 bank umum yang ada, 86 bank BOPOnya merangkak naik, namun kendati begitu sebagian bank masih bisa mencetak kenaikan laba dan bank yang menderita penurunan laba ada 54 bank.

Laba yang terus turun akan berdampak pada proses likuidasi. Pada Desember 2013, rasio kredit terhadap simpanan (LDR) perbankan telah mencapai 90\%, level tertinggi sejak krisis 1997/1998. Sepanjang Desember 2012 hingga Desember 2013, sistem perbankan telah menyalurkan dana pinjaman sebesar Rp594,2 triliun, sedangkan DPK yang dihimpun diperiode yang sama hanya Rp438,8 triliun. Dengan kata lain, telah terjadi net fund outflow sebesar Rp155,4 triliun. Kondisi ini jelas tidak stabil dan menimbulkan potensi risiko likuiditas yang signifikan bagi perbankan. Akibatnya, margin bunga bersih (NIM) akan tergerus dan mempengaruhi profitabilitas bank (LPS, 2014).

Likuiditas perbankan di awal triwulan II 2015 mulai longgar. Hal ini ditandai dengan penurunan rasio kredit terhadap simpanan atau LDR dari 91,7\% pada April 2014 menjadi $88,8 \%$ pada April 2015. Penurunan LDR ini disebabkan oleh pertumbuhan DPK yang lebih tinggi dari pertumbuhan kredit. Tekanan terhadap kinerja perbankan bukan hanya berasal dari melambatnya pertumbuhan kredit, tetapi juga dari potensi kenaikan jumlah kredit bermasalah. 
Berbagai faktor yang kurang menguntungkan mulai dari pelambatan pertumbuhan kredit, sumber daya yang tidak optimal, tingginya biaya dana serta kenaikan NPL menimbulkan tekanan pada tingkat profitabilitas perbankan (LPS, 2014).

Sejak 2012 perekonomian Indonesia terus mengalami banyak gejolak. Pada tahun 2013, pertumbuhan PDB turun menjadi di bawah $6 \%$ untuk pertama kalinya sejak krisis keuangan global, dan selama tahun 2014 pertumbuhan masih melambat. Mata uang yang terdepresiasi akan membantu mengendalikan impor namun permintaan dalam negeri yang kuat akan mendorong kembali impor sampai dengan tingkat tertentu, sehingga defisit transaksi berjalan masih tetap tinggi (OECD, 2015). Kondisi perbankan yang tidak kondusif tersebut juga berpengaruh besar terhadap makroekonomi di Indonesia terutama dari sektor pendapatan perkapita pada Produk Domestik Bruto (PDB), nilai inflasi, dan pengaruh dari dampak pertukaran nilai mata uang asing terhadap rupiah.

Adapun penelitian terdahulu yang melandasi penelitian ini diantaranya dilakukan oleh Budiarti (2014), menjelaskan modal, likuiditas, Produk Domestik Bruto (PDB) dan inflasi tidak dapat digunakan sebagai alat prediksi krisis perbankan. Profitabilitas dan nilai tukar dapat digunakan sebagai alat prediksi krisis dan berpengaruh signifikan serta berhubungan negatif terhadap prediksi krisis perbankan.
Penelitian Kibritcioglu (2002), menjelaskan jenis indeks kerapuhan sangat berguna dalam pengukuran dan monitoring kerapuhan sektor perbankan. Hasil penelitian menunjukkan BSF indeks yang diajukan dalam penelitian ini sangat membantu dalam pemantauan dan identifikasi sektor perbankan yang kesulitan dengan menggunakan data bulanan. Bank menjadi bangkrut secara eksplisit apabila bank terkena risiko dalam hal nilai aset dan kewajiban berubah di pasar keuangan. Artinya, semua bank berpotensi terkena berbagai jenis risiko ekonomi, seperti risiko likuiditas, risiko kredit dan risiko exchange rate. Indeks BSF mencerminkan perubahan iklim sektoral yang tepat sehingga secara signifikan mengurangi kemungkinan terjadinya krisis yang tinggi. Jika nilai indeks berkisar $-0,5<\mathrm{BSFI}<0$ maka sektor perbankan dianggap cukup rapuh, dan jika BSFI < -0,5 maka sangat rapuh. Setiap penurunan indeks BSF tidak selalu berarti bahwa sistem perbankan bergerak ke dalam sistemik krisis. Pada lanjutan penelitian Kibritcioglu (2003) yang menjelaskan bahwa kondisi Banking Sector Fragility di Indonesia dari tahun 1981 sampai 1989 cenderung stabil perkembangannya dan tidak menunjukkan kenaikan signifikan namun sampai akhir penelitian, indeks Banking Sector Fragility masih tergolong high fragility dengan indeks dibawah $-0,5$ seperti dijelaskan pada grafik di bawah ini:

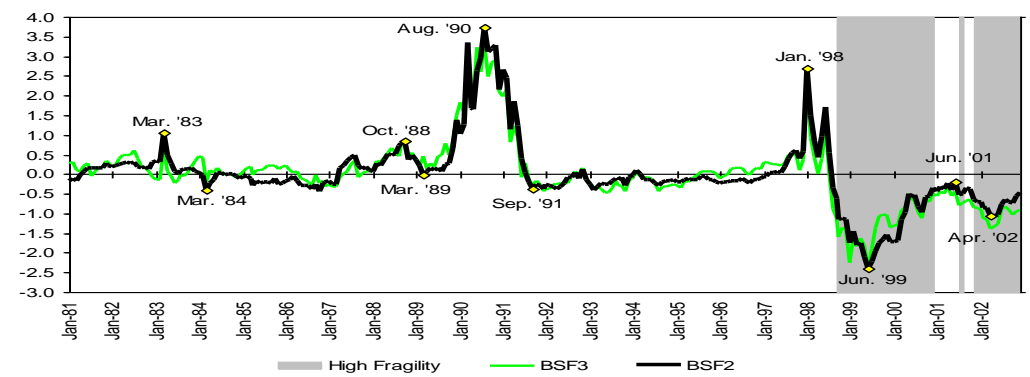

Grafik 1. Banking Sector Fragility di Indonesia (1981-2002)

(Sumber: Kibritcioglu, 2003) 


\begin{abstract}
Adapun identifikasi masalah dalam penelitian ini adalah terjadinya tren perlambatan pertumbuhan laba, perlambatan kredit dan pelemahan sektor riil, sumber daya yang tidak optimal, dan tingginya biaya dana operasional, serta modal kerja tidak sebanding dengan pendapatan menyebabkan adanya isu beberapa bank untuk melakukan merger dan dilikuidasi oleh Bank Indonesia. Akibatnya, margin bunga bersih (NIM) akan tergerus dan mempengaruhi profitabilitas bank, pertumbuhan PDB masih melambat, inflasi masih tinggi dalam masa krisis, dan pelemahan rupiah akan menurunkan penerimaan APBN. Oleh karena itu penelitian ini bermaksud untuk menilai sejauh mana permodalan, profitabilitas, likuiditas, Produk Domestik Bruto (PDB), nilai inflasi dan perubahan nilai tukar mempengaruhi krisis perbankan berbasis Banking Sector Fragility Index di Indonesia.
\end{abstract}

\section{KAJIAN LITERATUR DAN PENGEMBANGAN HIPOTESIS \\ Kajian literatur}

Sinyal dapat berupa informasi atau promosi lain yang menyatakan bahwa perusahaan tersebut lebih unggul dibandingkan perusahaan lainnya. Agar terlihat lebih unggul maka perusahaan harus sebaik mungkin menjaga kualitasnya (Krisnawati, 2014). Perusahaan yang sehat keuangannya cenderung untuk mengungkapkan informasi lebih banyak daripada perusahaan yang mengalami krisis. Dalam penelitian ini signaling theory menekankan kepada pentingnya informasi yang dikeluarkan bank terhadap kondisi keuangan yang teidentifikasi mengalami krisis. Apabila kondisi prediksi krisis diketahui, diharapkan dilakukan suatu tindakan untuk memperbaiki situasi tersebut sehingga suatu bank tidak akan masuk pada tahap kesulitan yang lebih berat seperti likuditas.

Teori-teori lain yang memiliki keterkaitan secara langsung terhadap penelitian ini adalah Stakeholder Theory. Menurut Budimanta (2008), stakeholders adalah individu, komunitas atau masyarakat baik secara keseluruhan maupun secara parsial yang memiliki hubungan serta kepentingan terhadap perusahaan. Individu, kelompok, komunitas, dan masyarakat dikatakan sebagai stakeholders jika memiliki karakteristik yaitu mempunyai kekuasaan, legitimasi, dan kepentingan terhadap perusahaan. Pemerintah dikategorikan sebagai stakeholders bagi perusahaan dikarenakan pemerintah mempunyai kepentingan atas aktivitas perusahaan.

Krisis perbankan berbasis Banking Sector Fragility Index di Indonesia dipengaruhi oleh sektor ekonomi makro dan sektor ekonomi mikro diantaranya permodalan, profitabilitas, likuiditas, Produk Domestik Bruto (PDB), nilai inflasi dan perubahan nilai tukar.

1. Permodalan

CAR yang dimiliki semakin rendah berarti semakin kecil modal bank yang dimiliki untuk menanggung aktiva berisiko, sehingga semakin besar kemungkinan bank akan mengalami kondisi bermasalah karena modal yang dimiliki bank tidak cukup menanggung penurunan nilai aktiva berisiko. Berdasarkan Peraturan Bank Indonesia No 6/10/PBI/2004 standar CAR adalah $8 \%$. CAR yang ditetapkan oleh Bank Indonesia mengacu pada standar internasional yang dikeluarkan oleh Banking for International Settlement.

2. Profitabilitas

Penelitian

Budiarti menyatakan bank yang memiliki $R O A$ yang rendah berkinerja keuangan yang kurang baik dan tidak dapat menghasilkan return bagi perusahaan. Baskoro (2014) berpendapat bahwa $R O E$ yaitu rasio yang mengukur kemampuan perusahaan menghasilkan laba berdasarkan modal saham tertentu dan rasio ini terbukti signifikan. Semakin rendah rasio ROE maka, kemungkinan suatu bank dalam kondisi bermasalah semakin besar. 
Variabel NIM merupakan rasio yang mengukur kemampuan bank dalam mengelola aktiva produktif untuk menghasilkan pendapatan bunga dari kegiatan operasional bank. Rasio ini terbukti signifikan mempengaruhi krisis sesuai dengan hasil penelitian Kibritcioglu (2002) yang menyatakan bahwa pertumbuhan kredit yang berlebihan memicu kerapuhan perbankan dengan adanya kredit bermasalah yang akan mengurangi sektor laba.

BOPO menggambarkan beban bunga yang harus dibayar dan pendapatan bank. Beban bunga yang harus dibayar sangat tergantung dengan variabel makro. Rakhmawati dan Hermana (2005) menyatakan bahwa semakin besar rasio BOPO yang dimiliki bank semakin rendah tingkat efisiensi bank tersebut sehingga pendanaan untuk pengembangan usaha semakin rendah yang memicu terjadinya krisis perbankan.

3. Likuiditas

LDR merupakan ukuran seberapa jauh kemampuan bank dalam membayar kembali penarikan dana yang dilakukan deposan dengan mengandalkan kredit yang diberikan sebagai sumber likuiditas. Almilia dan Herdinigtyas (2005) menyatakan bahwa rasio LDR digunakan untuk menilai likuiditas suatu bank yang dengan cara membagi jumlah kredit yang diberikan oleh bank terhadap dana pihak ketiga. Menurut Kanya dan Tri (2015) NPL dapat digunakan untuk memprediksi potensi terjadinya kondisi bermasalah bank. Semakin tinggi rasio ini maka akan semakin buruk kualitas kredit bank yang menyebabkan jumlah kredit bermasalah semakin besar dan menurunkan kemampuan dalam pencapaian rasio keuntungan. Hal ini dikarenakan jenis risiko ini merupakan risiko terbesar (sistemik) dalam sistem perbankan Indonesia dan dapat menjadi penyebab utama kegagalan bank.
4. Produk Domestik Bruto (PDB

PDB merupakan indikator makro ekonomi yang mempengaruhi profitabilitas bank. Jika PDB tinggi maka akan meningkatkan daya simpan masyarakat dan kemampuan memimjam bagi pengusaha besar, begitu sebaliknya penurunan PDB akan berimplikasi pada penurunan pendapatan, kesempatan kerja dan standar hidup produk domestik bruto rill tidaklah selalu meningkat atau menurun, tetapi naik dan turun secara bergantian membentuk fluktuasi yang tidak tetap dan berubah-ubah sepanjang waktu. Aviliani, dkk (2015) berpendapat bahwa variabel makroekonomi dari PDB berpengaruh terhadap prediksi krisis perbankan.

5. Inflasi

Inflasi yang tinggi akan menyebabkan pendapatan riil masyarakat akan terus turun sehingga standar hidup dari masyarakat. Menurut Aviliani, dkk (2015) peningkatan inflasi dapat menyebabkan peningkatan biaya operasional bank, sehingga dengan asumsi pendapatan operasional tetap maka nilai BOPO akan meningkat. Inflasi juga dapat meningkatkan risiko kredit dan potensi macetnya pembayaran pinjaman, sehingga NPL meningkat. Inflasi yang diakibatkan oleh perkembangan siklus bisnis akan menyebabkan perekonomian mengalami booming.

6. Nilai tukar

Fluktuasi perubahan nilai tukar akan menimbulkan risiko. Semakin tinggi fluktuasinya maka risikonya akan semakin besar, dan sebaliknya semakin rendah fluktuasinya maka risikonya akan semakin kecil. Nilai tukar akan mata uang asing menjadi perhatian bank karena mampu mempengaruhi tingkat profitabilitas bank. Dengan terjadinya fluktuasi akan nilai tukar mata uang asing, bank dapat memperoleh pendapatan berupa fee dan selisih kurs (Budiarti, 2014). 


\section{Pengembangan Hipotesis}

Berdasarkan penelitian terdahulu yang dilakukan oleh Almilia dan Herdinigtyas (2005), CAR mempunyai pengaruh negatif artinya semakin rendah rasio ini maka semakin besar kemungkinan suatu bank dalam kondisi bermasalah. Hasil penelitian ini didukung oleh Cihak dan Poghosyan (2009) dan Gunsel (2007) yang menemukan bahwa modal yang tidak memadai merupakan variabel penting yang menentukan kegagalan bank.

Penelitian-penelitan terdahulu menguji pengaruh profitabilitas pada empat variabel uji (ROA, ROE, NIM dan BOPO) terhadap prediksi krisis perbankan. Pada variabel ROA penelitian dilakukan Budiarti (2014) yaitu bank yang memiliki ROA yang rendah menunjukkan bahwa bank tersebut berkinerja keuangan yang kurang baik dan tidak dapat menghasilkan return bagi perusahaan. ROA signifikan terhadap prediksi krisis perbankan. Kanya dan Tri (2015) menyatakan bahwa ROA dapat memprediksi terjadinya kondisi bermasalah bank. Rendahnya kemampuan perbankan dalam peningkatan keuntungan bank atas penggunaan aktiva yang dimiliki menjadikan kemampuan bank juga mengalami penurunan dan kemungkinan terjadinya permasalahan perbankan juga tinggi. Hasil penelitian lainnya juga mengemukakan hal yang sama bahwa ROA berpengaruh signifikan terhadap nilai krisis perbankan, seperti yang dilakukan oleh Gunsel (2007), Domaç dan Peria (2000), Rakhmawati dan Hermana (2005), Baskoro (2014) dan Cihak dan Poghosyan (2009).

Baskoro (2014) dan Cihak dan Poghosyan (2009) juga melakukan pengujian pada variabel ROE, semakin rendah rasio ROE maka kemungkinan suatu bank dalam kondisi bermasalah semakin besar. Pendapat yang sama didukung oleh Degryse, et al. (2013). Pengujian variabel NIM dijelaskan oleh Aviliani, dkk (2015). NIM merupakan variabel yang memiliki hubungan paling lemah dengan hampir semua variabel makro dan
Kibritcioglu (2002) menyatakan bahwa pertumbuhan kredit yang berlebihan memicu kerapuhan perbankan dengan adanya kredit bermasalah yang akan mengurangi sektor laba. Aviliani, dkk (2015) juga menjelaskan variabel uji BOPO yakni secara rata-rata BOPO merupakan indikator perbankan yang memiliki respon terbesar terhadap guncangan yang terjadi pada variabel makroekonomi. Dengan asumsi pendapatan operasional konstan maka rasio BOPO akan mengalami kenaikan. Penelitian ini didukung oleh Rakhmawati dan Hermana (2005) semakin besar rasio BOPO yang dimiliki bank semakin rendah tingkat efisiensi bank tersebut sehingga pendanaan untuk pengembangan usaha semakin rendah yang memicu terjadinya krisis perbankan. Kemudian Almilia dan Herdinigtyas (2005) mengemukakan rasio BOPO mempunyai pengaruh positif artinya semakin tinggi rasio ini maka kemungkinan suatu bank dalam kondisi bermasalah semakin besar. Pengaruhnya terhadap kondisi bermasalah adalah signifikan.

Penelitian pengaruh likuiditas pada 2 variabel uji (LDR dan NIM) terhadap prediksi krisis perbankan untuk variabel uji LDR dilakukan oleh Kibritcioglu (2002), Bruinshoofd, et al. (2008), Degryse, et al., (2013) Gunsel (2007), Domaç dan Peria (2000), Rakhmawati dan Hermana (2005), Mulyaningrum (2008) dan Almilia dan Herdinigtyas (2005), mereka menyimpulkan LDR berpengaruh signifikan terhadap prediksi krisis perbankan. Semakin besar rasio ini menunjukkan semakin rendahnya tingkat likuiditas yang dimiliki bank sehingga dapat meningkatkan potensi terjadinya kondisi bermasalah bank, karena bank tidak memiliki cukup dana untuk memenuhi penarikan dana pihak ketiga dan terlalu banyak menyalurkan kredit yang bisa meningkatkan risiko gagal bayar dan berdampak sistemik.

Adapun untuk variabel uji NPL penelitian juga dilakukan oleh Kibritcioglu (2002), Bruinshoofd, et al. (2008), Rakhmawati dan 
Hermana (2005) dan Aviliani, dkk (2015), penelitian tersebut menyimpulkan nilai NPL mempunyai berpengaruh signifikan terhadap prediksi krisis perbankan. Kanya dan Tri (2015) berpendapat semakin tinggi rasio ini maka akan semakin buruk kualitas kredit bank yang menyebabkan jumlah kredit bermasalah semakin besar dan menurunkan kemampuan dalam pencapaian rasio keuntungan. Hal ini dikarenakan jenis risiko ini merupakan risiko terbesar (sistemik) dalam sistem perbankan Indonesia dan dapat menjadi penyebab utama kegagalan bank.

Penelitian pengaruh PDB terhadap prediksi krisis dilakukan oleh Kanya dan Tri (2015), Bruinshoofd, et al (2008), Cihak dan Poghosyan (2009), Domaç dan Peria (2000), Aviliani, dkk (2015) dan Oktavia (2008) yang menyimpulkan bahwa variabel makroekonomi dari PDB berpengaruh terhadap prediksi krisis perbankan.

Penelitian pengaruh inflasi terhadap prediksi krisis perbankan dilakukan oleh Cihak dan Poghosyan (2009), Domaç dan Peria (2000) dan Aviliani, dkk (2015) menyimpulkan bahwa variabel makroekonomi dari inflasi berpengaruh terhadap prediksi krisis perbankan. Aviliani, dkk (2015) menyatakan bahwa peningkatan inflasi dapat menyebabkan peningkatan biaya operasional bank, sehingga dengan asumsi pendapatan operasional tetap maka nilai BOPO akan meningkat. Inflasi juga dapat meningkatkan risiko kredit dan potensi macetnya pembayaran pinjaman, sehingga NPL meningkat. Inflasi yang diakibatkan oleh perkembangan siklus bisnis akan menyebabkan perekonomian mengalami booming. Inflasi yang terjadi karena hal tersebut biasanya berpengaruh lebih besar terhadap sisi penerimaan dibandingkan dari sisi biaya manajemen bank tidak mengantisipasi perubahan inflasi, maka suku bunga mengalami penyesuaian yang lamban, sehingga peningkatan biaya lebih cepat dibandingkan peningkatan pendapatan, dan akhirnya inflasi berdampak negatif terhadap profitabilitas.

Penelitian pengaruh nilai tukar terhadap prediksi krisis dilakukan oleh (Budiarti, 2014) dan Kanya dan Tri (2015) menemukan bahwa dengan terjadinya fluktuasi akan nilai tukar mata uang asing, bank dapat memperoleh pendapatan berupa fee dan selisih kurs.

Berdasarkan kajian teoritis dan empiris maka dalam penelitian ini dapat dirumuskan hipotesis sebagai berikut :

$\mathrm{H}_{1}$ : Permodalan (CAR) diduga dapat digunakan sebagai alat prediksi krisis perbankan berbasis Banking Sector Fragility Index di Indonesia.

$\mathrm{H}_{2}$ : Profitabilitas diduga dapat digunakan sebagai alat prediksi krisis perbankan berbasis Banking Sector Fragility Index di Indonesia.

$\mathrm{H}_{3}$ : Likuiditas diduga dapat digunakan sebagai alat prediksi krisis perbankan berbasis Banking Sector Fragility Index di Indonesia.

$\mathrm{H}_{4}$ : Produk Domestik Bruto diduga dapat digunakan sebagai alat prediksi krisis perbankan berbasis Banking Sector Fragility Index di Indonesia.

$\mathrm{H}_{5}$ : Inflasi diduga dapat digunakan sebagai alat prediksi krisis perbankan berbasis Banking Sector Fragility Index di Indonesia.

$\mathrm{H}_{6}$ : Nilai tukar diduga dapat digunakan sebagai alat prediksi krisis perbankan berbasis Banking Sector Fragility Index di Indonesia.

\section{Metodologi Penelitian \\ Populasi dan Teknik Penarikan Sampel}

Dalam penelitian ini yang menjadi populasi adalah bank umum nasional yang terdaftar di Bursa Efek Indonesia dengan periode pengamatan tahun 2010-2014. Teknik pengambilan sampel menggunakan teknik purposive sampling methods dengan kriteria yaitu bank memiliki data yang lengkap terkait dengan variabel yang digunakan 
dalam penelitian dengan mata uang rupiah dalam laporan keuangan lengkap dan memiliki ukuran Bank Sector Fragility dengan nilai indeks $<-0.5$ sampai $>0$. Kemudian data yang digunakan adalah data sekunder yang merupakan data laporan keuangan yang dijadikan sampel tersedia di halaman website Bursa Efek Indonesia (www.idx.co.id), www.bi.co.id, dan www.bps.go.id.

\section{Operasionalisasi Variabel}

Dalam penelitian ini yang menjadi variabel independen adalah modal profitabilitas, likuiditas, PDB, inflasi dan nilai tukar. Sedangkan yang menjadi variabel dependen adalah prediksi krisis perbankan.

Tabel 1. Operasionalisasi Variabel

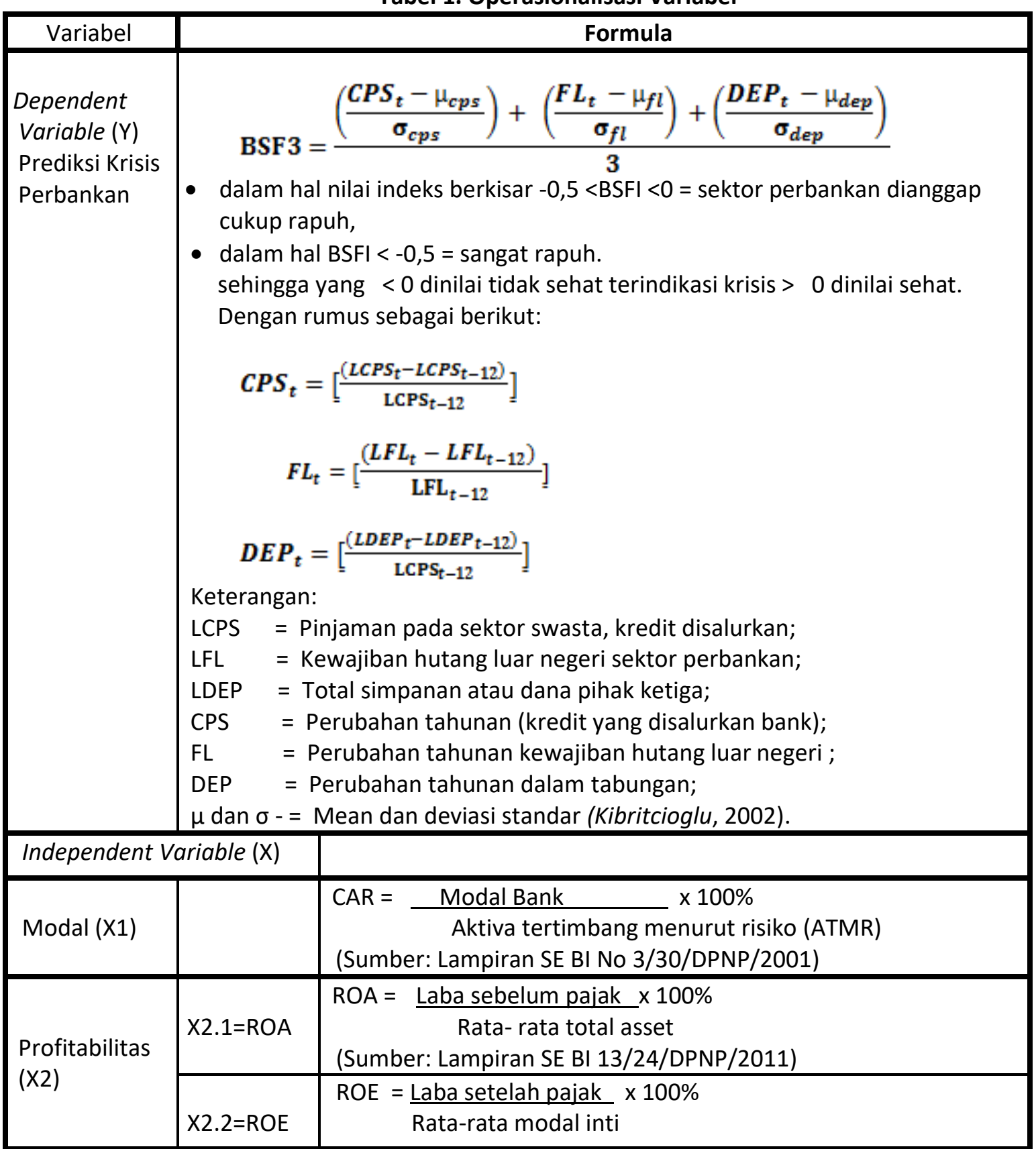

JIAFE (Jurnal Ilmiah Akuntansi Fakultas Ekonomi)

Volume 3 No. 2 Tahun 2017, Hal. 1-16 


\begin{tabular}{|c|c|c|}
\hline & & (Sumber: Lampiran SE BI 13/24/DPNP/2011) \\
\hline & $\mathrm{X} 2.3=\mathrm{NIM}$ & $\begin{array}{l}\text { NIM }=\frac{\text { Pendapatan bunga bersih }}{\text { Rata-rata aktiva produktif }} \times 100 \% \\
\text { (Sumber: Lampiran SE BI 13/24/DPNP/2011) }\end{array}$ \\
\hline & $\begin{array}{l}\mathrm{X} 2.4=\mathrm{BOP} \\
\mathrm{O}\end{array}$ & $\begin{array}{l}\text { BOPO }=\frac{\text { Total beban operasional }}{\text { Total pendapatan operasional }} \times 100 \% \\
\text { (Sumber: Lampiran SE BI 13/24/DPNP/2011) }\end{array}$ \\
\hline \multirow[b]{2}{*}{ Likuiditas (X3) } & X3.1=LDR & $\begin{array}{l}\text { LDR }=\frac{\text { Kredit }}{\text { Dana pihak ketiga }} \\
\text { (Sumber: SE BI 13/24/DPNP/2011) }\end{array}$ \\
\hline & $X 3.2=N P L$ & $\begin{array}{l}\text { NPL }=\frac{\text { Kredit bermasalah }}{\text { Total Kredit }} \times 100 \% \\
\text { (Sumber: SE BI 13/24/DPNP/2011) }\end{array}$ \\
\hline Pdb (X4) & & $\begin{array}{l}\text { PDB Riil = Output Fisik Tahun Sekarang x Harga Pada Tahun Basis } \\
\text { (www.bi.go.id) }\end{array}$ \\
\hline Inflasi (X5) & & $\begin{array}{l}\text { Indeks Harga Konsumen (IHK) }=\frac{\text { Harga Sekarang } \times 100 \%}{\text { Harga Tahun Dasar }} \\
\text { (www.bi.go.id) }\end{array}$ \\
\hline $\begin{array}{l}\text { Nlai tukar } \\
\text { (X6) }\end{array}$ & & $\begin{array}{l}\mathrm{Q}=\mathrm{S} \underline{\mathrm{P}} \\
\mathrm{P} * \\
\mathrm{Q}=\text { Nilai tukar riil. } \\
\mathrm{S}=\text { Nilai tukar nominal. } \\
\mathrm{P}=\text { Tingkat harga domestik dan } \\
\mathrm{P}^{*}=\text { Tingkat harga di luar negeri (Simorangkir dan Suseno, } \\
2004)\end{array}$ \\
\hline
\end{tabular}

\section{Teknik Analisis Data}

Teknik analisis data dalam penelitian ini menggunakan pendekatan statistik yaitu analisis statistik deskriptif dan regresi logistic. Pengujian statistik dalam penelitian ini akan menggunakan bantuan software Statistical Product and Service Solution (SPSS) versi 23. Model regresi yang digunakan dalam penelitian ini ditunjukkan dalam persamaan sebagai berikut:

$\mathrm{Y}=\beta_{0}+\beta_{1}$ (modal) $+\beta_{2}$ (likuiditas) + $\beta_{3}$ (profitabilitas $)+\beta_{4}($ PDB $)+\beta_{5}($ inflasi $)+$ $\beta_{6}($ nilai tukar $)+e$
Keterangan:

$\mathrm{Y}=$ Prediksi krisis

$\beta_{0}=$ Konstanta

$\beta=$ Koefisien regresi model

$X_{n}=$ Rasio-rasio keuangan dipilih secara

statistik

$\mathrm{E}=$ Eror

\section{Hasil penelitian dan Pembahasan}

Berdasarkan hasil uji keseluruhan maka diperoleh hasil penelitian sebagai berikut: 
Tabel 4.1 Rangkuman Uji Kelayakan dari Model Regresi Logistik

\begin{tabular}{|l|l|l|}
\hline Model Pengujian & $\begin{array}{l}\text { Hasil uji } \\
\text { kelayakan }\end{array}$ & \multicolumn{1}{|c|}{ Kesimpulan } \\
\hline Log likehood & 512,513 & Model baik \\
\hline $\begin{array}{l}\text { Hosmer and Lemeshow } \\
\text { goodness of fit test. }\end{array}$ & 0,271 & Model regresi layak untuk analisa selanjutnya. \\
\hline $\begin{array}{l}\text { Omnibus Test of Model } \\
\text { Coefficient }\end{array}$ & 0,000 & Model fit. \\
\hline $\begin{array}{l}\text { Cox \& Snell's R Square } \\
\text { Nagelkerke's R Square }\end{array}$ & 0,218 & $\begin{array}{l}\text { Variabel dependen mampu men } \\
\text { pengaruh variabel independen. }\end{array}$ \\
\hline $\begin{array}{l}\text { Ketepatan prediksi } \\
\text { dalam model }\end{array}$ & $85,4 \%$ & $\begin{array}{l}\text { Variabel dependen mampu menjelaskan } \\
\text { pengaruh variabel independen. }\end{array}$ \\
\hline
\end{tabular}

Sumber: Data sekunder yang telah diolah, 2016

Tabel 4.1 Rangkuman Hasil Uji Penelitian

\begin{tabular}{|c|c|c|c|}
\hline \multicolumn{2}{|l|}{ Variabel } & $\begin{array}{l}\text { Signifikasi } \\
\text { hasil uji }\end{array}$ & Kesimpulan \\
\hline \multicolumn{2}{|c|}{ Modal (X1) CAR } & $0,164>0,05$ & $\begin{array}{l}\text { CAR tidak berpengaruh terhadap krisis } \\
\text { perbankan berbasis Banking Sector Fragility } \\
\text { Index di Indonesia. }\end{array}$ \\
\hline \multirow{4}{*}{$\begin{array}{l}\text { Profitabilitas } \\
\text { (X2) }\end{array}$} & $\times 2.1=\mathrm{ROA}$ & $0,217>0,05$ & $\begin{array}{l}\text { ROA tidak berpengaruh terhadap krisis } \\
\text { perbankan berbasis Banking Sector Fragility } \\
\text { Index di Indonesia. }\end{array}$ \\
\hline & $X 2.2=\mathrm{ROE}$ & $0,000<0,05$ & $\begin{array}{l}\text { ROE berpengaruh terhadap krisis perbankan } \\
\text { berbasis Banking Sector Fragility Index di } \\
\text { Indonesia. }\end{array}$ \\
\hline & $X 2.3=\mathrm{NIM}$ & $0,000<0,05$ & $\begin{array}{l}\text { NIM berpengaruh terhadap krisis perbankan } \\
\text { berbasis Banking Sector Fragility Index di } \\
\text { Indonesia. }\end{array}$ \\
\hline & $\begin{array}{c}\mathrm{X} 2.4=\mathrm{BOP} \\
\mathrm{O}\end{array}$ & $0,001<0,05$ & $\begin{array}{l}\text { BOPO berpengaruh terhadap krisis perbankan } \\
\text { berbasis Banking Sector Fragility Index di } \\
\text { Indonesia. }\end{array}$ \\
\hline \multirow{2}{*}{$\begin{array}{l}\text { Likuiditas } \\
\text { (X3) }\end{array}$} & X3.1=LDR & $0,000<0,05$ & $\begin{array}{l}\text { LDR berpengaruh terhadap krisis perbankan } \\
\text { berbasis Banking Sector Fragility Index di } \\
\text { Indonesia. }\end{array}$ \\
\hline & $X 3.2=N P L$ & $0,506 \geq 0,05$ & $\begin{array}{l}\text { NPL tidak berpengaruh terhadap krisis } \\
\text { perbankan berbasis Banking Sector } \\
\text { Fragility Index di Indonesia. }\end{array}$ \\
\hline \multicolumn{2}{|l|}{$\mathrm{Pdb}(\mathrm{X} 4)$} & $0,900 \geq 0,05$ & $\begin{array}{l}\text { PDB tidak berpengaruh terhadap krisis } \\
\text { perbankan berbasis Banking Sector Fragility } \\
\text { Index di Indonesia. }\end{array}$ \\
\hline
\end{tabular}




\begin{tabular}{|l|l|l|}
\hline Inflasi (X5) & $0,917 \geq 0,05$ & $\begin{array}{l}\text { Inflasi tidak berpengaruh terhadap krisis } \\
\text { perbankan berbasis Banking Sector Fragility } \\
\text { Index di Indonesia. }\end{array}$ \\
\hline Nilai tukar (X6) & $0,164 \geq 0,05$ & $\begin{array}{l}\text { Nilai tidak berpengaruh terhadap krisis } \\
\text { perbankan berbasis Banking Sector Fragility } \\
\text { Index di Indonesia. }\end{array}$ \\
\hline
\end{tabular}

Sumber: Data sekunder yang telah diolah,2016

Dari hasil penelitian tersebut di atas dapat diketahui pengaruh dari masing masing variabel yaitu:

1. Pengaruh modal sebagai alat prediksi krisis perbankan berbasis Banking Sector Fragility Index di Indonesia

Tidak ditemukan pengaruh yang signifikan antara modal terhadap probabilitas krisis perbankan disebabkan karena keseluruhan bank yang menjadi sampel telah mempunyai CAR yang tinggi selama pengamatan dengan rata-rata sebesar $14,35 \%$. Hal ini disebabkan jumlah modal yang dimiliki bank lebih besar dari jumlah Aktiva Tertimbang Menurut Risiko (ATMR), sehingga menyebabkan bank memiliki CAR yang lebih tinggi dan CAR tidak berpengaruh signifikan terhadap krisis perbankan karena adanya peraturan Bank Indonesia tentang CAR bank umum minimal $8 \%$. Hasil penelitian yang tidak konsisten dengan hipotesis ini didukung oleh Mulyaningrum (2008) yang menyatakan bahwa variabel CAR tidak ditemukan bukti adanya pengaruh CAR terhadap probabilitas kebangkrutan bank di Indonesia. Penelitian lain mempertegas hal yang sama, yaitu Kanya dan Tri (2015), Bruinshoofd, et al. (2008), Degryse, et al., (2013), Rakhmawati dan Hermana (2005) dan Baskoro (2014) yang menyatakan bahwa CAR tidak berpengaruh terhadap prediksi krisis perbankan. CAR yang dimiliki oleh perbankan di Indonesia sudah memenuhi ketentuan modal minimum yang ditetapkan oleh Bank Indonesia.
2. Pengaruh profitabilitas sebagai alat prediksi krisis perbankan berbasis Banking Sector Fragility Index di Indonesia

Profitabilitas dapat digunakan alat sebagai prediksi krisis perbankan berbasis Banking Sector Fragility Index di Indonesia. Dari 4 variabel uji yang dilakukan hanya ROA saja tidak berpengaruh terhadap krisis perbankan berbasis Banking Sector Fragility Index di Indonesia. Tidak berpengaruhnya ROA secara signifikan terhadap probabilitas krisis perbankan berbasis Banking Sector Fragility Index di Indonesia mengindikasikan hampir semua manajemen bank berupaya untuk meningkatkan laba. Oleh sebab itu setiap perbankan berupaya mematuhi peraturan perundangan yang berlaku untuk bisa dikatagorikan dalam bank sehat. Semakin besar ROA, semakin besar pula tingkat keuntungan yang dicapai bank sehingga kemungkinan suatu bank dalam krisis semakin kecil, sehingga dapat disimpulkan pengaruh profitabilitas pada variabel ROA tidak dapat dijadikan sebagai alat penentu prediksi krisis perbankan berbasis Banking Sector Fragility Index di Indonesia. Hasil penelitian ini sesuai dengan Almilia dan Herdinigtyas (2005) Semakin besar ROA, semakin besar pula tingkat keuntungan yang dicapai bank sehingga kemungkinan suatu bank dalam kondisi bermasalah semakin kecil. Pengaruhnya terhadap kondisi bermasalah tidak signifikan karena tingkat signifikansi di atas 0,05. Ketidakkonsistenan hasil penelitian ini dengan hipotesis didukung juga oleh penelitian Mulyaningrum (2008) 
yang menemukan bahwa ROA menjadi positif disebabkan laba yang dimiliki bank tinggi namun kredit yang diberikan bank sedikit dan Aviliani, dkk (2015) menyimpulkan ROA tidak berpengaruh signifikan terhadap probabilitas kebangkrutan bank di Indonesia.

ROE berpengaruh signifikan terhadap prediksi krisis perbankan berbasis Banking Sector Fragility Index di Indonesia. Dengan banyaknya sampel bank bernilai ROE rendah di bawah standar minimum menunjukkan rata-rata bank dalam penelitian ini memiliki kinerja keuangan yang kurang baik dengan tidak dapat menghasilkan laba baik bagi perusahaan maupun bagi pemegang saham dan adanya ROE yang tidak mempertimbangkan risiko bagi investor memberi celah terhadap terjadinya krisis perbankan bila tidak berimbang antara laba atas pengelolaan Dana Pihak Ketiga (DPK) dan kredit macet yang ditimbulkan. Dengan demikian dapat disimpulkan pengaruh profitabilitas pada variabel ROE dapat dijadikan sebagai alat penentu prediksi krisis perbankan berbasis Banking Sector Fragility Index di Indonesia. Hal ini konsisten dengan penelitian Baskoro (2014) Return on Equity (ROE) yaitu rasio yang mengukur kemampuan perusahaan menghasilkan laba berdasarkan modal saham tertentu dan rasio ini terbukti signifikan. Semakin rendah rasio ROE maka, kemungkinan suatu bank dalam kondisi bermasalah semakin besar. Pendapat yang sama juga didukung oleh penelitian Degryse, et al. (2013), Cihak dan Poghosyan (2009) yang menyatakan rasio ROE berpengaruh signifikan terhadap prediksi krisis perbankan.

NIM rendah di bawah standar minimum menunjukkan rata-rata bank dalam penelitian ini berkinerja keuangan kurang baik sehingga tidak dapat menghasilkan laba baik bagi perusahaan.
Maka dapat disimpulkan pengaruh profitabilitas pada variabel NIM dapat dijadikan sebagai alat penentu prediksi krisis perbankan. Hasil analisis penelitian ini konsisten dengan penelitian Kibritcioglu (2002) yang menyatakan bahwa pertumbuhan kredit yang berlebihan memicu kerapuhan perbankan dengan adanya kredit bermasalah yang akan mengurangi pendapatan bunga bersih sebagai bagian dari sektor dan untuk sektor makroekonomi. Pengaruh nilai NIM lebih dipertegas oleh Aviliani, dkk (2015) bahwa NIM merupakan variabel yang memiliki hubungan paling lemah dengan hampir semua variabel makro yang berarti nilai NIM mampu memicu krisis perbankan karena rendahnya laba yang akan mempengaruhi penurunan nilai inflasi, PDB dan nilai tukar dari kredit valas.

Besarnya nilai BOPO dalam penelitian ini dimungkinkan karena adanya proses pengembangan usaha perbankan dengan banyaknya bank melakukan pembukaan cabang operasional baru di seluruh Indonesia, sehingga biaya operasional besar tidak diikuti oleh pertumbuhan laba yang besar, akhirnya memberi peluang terhadap terjadinya krisis. Hasil penelitian konsisten dengan penelitian Aviliani, $d k k$ (2015) bahwa secara rata-rata BOPO merupakan indikator perbankan yang memiliki respon terbesar terhadap guncangan yang terjadi pada variabel makroekonomi. Hasil ini didukung oleh Rakhmawati dan Hermana (2005) bahwa semakin besar rasio BOPO yang dimiliki bank semakin rendah tingkat efisiensi bank tersebut sehingga pendanaan untuk pengembangan usaha semakin rendah yang memicu terjadinya krisis perbankan dan Almilia dan Herdinigtyas (2005) memperjelaskan rasio BOPO mempunyai pengaruh positif artinya semakin tinggi rasio ini maka kemungkinan suatu bank 
dalam kondisi bermasalah semakin besar. Pengaruhnya terhadap kondisi bermasalah adalah signifikan.

3. Pengaruh likuiditas sebagai alat prediksi krisis perbankan berbasis Banking Sector Fragility Index di Indonesia

Hasil ini mengindikasikan rata-rata keseluruhan bank nilai LDR tinggi dengan nilai rata-rata sebesar $84.4136 \%$. Kondisi ini dapat terjadi karena kredit yang diberikan oleh sebagian bank terbilang cukup tinggi jika dibandingkan dengan dana pihak ketiga yang diperoleh, sehingga rasio LDR yang dimiliki oleh bank ikut tinggi. Dengan masih banyaknya bank yang memiliki nilai LDR di atas standar minimum yang menunjukkan bank tersebut memiliki kinerja keuangan yang kurang baik sehingga tidak mampu mengelola risiko likuditas maka dapat disimpulkan pengaruh likuiditas pada variabel LDR dapat dijadikan sebagai alat penentu prediksi krisis perbankan berbasis Banking Sector Fragility Index di Indonesia. Hasil penelitian ini konsisten dengan penelitian Mulyaningrum (2008), LDR berpengaruh signifikan terhadap probabilitas kebangkrutan bank di Indonesia dengan nilai signifikansi sebesar 0,049 . Nilai koefisien yang negatif tidak sesuai dengan hipotesis yang diajukan. Hal ini disebabkan karena jumlah kredit yang diberikan bank relatif rendah sedangkan dana yang dihimpun bank tinggi yang menyebabkan biaya bunga yang ditanggung relatif lebih tinggi dari pendapatan bunga sehingga probabilitas bank mengalami kebangkrutan menjadi tinggi.

Hasil penelitian ini bertentangan dengan kerangka pemikiran dan hipotesis yakni rasio likuiditas diduga dapat digunakan sebagai alat prediksi krisis perbankan, yang konsisten dengan penelitian Kibritcioglu (2002), Kanya dan Tri (2015), Bruinshoofd, et al (2008),
Rakhmawati dan Hermana (2005), dan Aviliani, $d k k$ (2015) menyatakan nilai NPL mempunyai berpengaruh signifikan terhadap prediksi krisis perbankan.Tidak berpengaruhnya NPL secara signifikan terhadap prediksi krisis perbankan berbasis Banking Sector Fragility Index di Indonesia mengindikasikan rata-rata keseluruhan bank memiliki NPL rendah dengan rata- rata nilai NPL sebesar $2,8784 \%$. Dengan demikian dapat dikatakan bahwa rata-rata bank yang dijadikan sampel telah memiliki NPL yang baik.Dalam hal ini rata-rata bank sudah menerapkan peraturan pemerintah tentang besarnya rasio NPL maksimum sebesar $5 \%$ sehingga setiap bank selalu berusaha memegang prinsip kehati-hatian dalam mengelola likuiditasnya. Kondisi ini dapat terjadi karena pengalaman krisis ekonomi Indonesia tahun 1996 telah mengajarkan industri perbankan untuk berhati-hati dalam mengatur likuiditasnya. Analisa dari penelitian ini didukung oleh Mulyaningrum (2008) NPL tidak berpengaruh secara signifikan terhadap probabilitas kebangkrutan bank di Indonesia mengindikasikan rata-rata sampel penelitian sudah memenuhi batas maksimal NPL sebesar 5\%, sehingga dapat disimpulkan pengaruh likuiditas pada variabel NPL tidak dapat dijadikan sebagai alat penentu prediksi krisis perbankan.

4. Pengaruh Produk Domestik Bruto sebagai alat prediksi krisis perbankan berbasis Banking Sector Fragility Index di Indonesia

Hasil penelitian ini bertentangan dengan kerangka pemikiran dan hipotesis. Tidak berpengaruhnya PDB secara signifikan terhadap prediksi krisis perbankan berbasis Banking Sector Fragility Index di Indonesia mengindikasikan nilai PDB selama penelitian kecenderungan meningkat. Pengaruh nilai PBD ini terhadap sektor perbankan terkait dengan penyaluran 
kredit yang dilakukan perbankan yang memberikan kontribusi terhadap perekonomian. Berdasarkan data Badan Pusat Statistik di Indonesia, kontribusi pengeluaran konsumsi rumah tangga memiliki porsi yang paling besar dalam menyumbang PDB dibandingkan dengan komponen yang lain. Secara umum kontribusi dari pengeluaran konsumsi rumah tangga ini menyumbang rata-rata $54,35 \%$ pada lima tahun terakhir. Tingginya kontribusi pengeluaran konsumsi rumah tangga terhadap pembentukan PDB Indonesia mengindikasikan kecenderungan untuk mengkonsumsi masyarakat Indonesia cenderung tinggi. Berdasarkan analisa tersebut diketahui kenaikan PDB lebih digunakan untuk konsumsi dari pada menabung atau investasi, sehingga PDB tidak mempengaruhi masyarakat berinvestasi dan melakukan permintaan kredit dan dampak yang diberikan oleh penurunan dan kenaikan PDB tidak terlalu dirasakan oleh bank-bank di Indonesia maka dapat disimpulkan variabel PDB tidak dapat dijadikan sebagai alat penentu prediksi krisis perbankan.

Analisa dari penelitian ini sama dengan Budiarti (2014) variabel PDB tidak signifikan didukung dengan fakta angka PDB pada tahun 2008 sampai dengan tahun 2012 terus mengalami kenaikan dengan rasio kredit perbankan terhadap PDB pada tahun 2012 hanya sebesar 32\%. Cukup rendahnya rasio kredit perbankan terhadap PDB membuat kemungkinan terjadinya kredit macet juga semakin kecil sehingga dampak yang diberikan oleh penurunan dan kenaikan PDB tidak terlalu dirasakan oleh bank-bank di Indonesia.

5. Pengaruh inflasi sebagai alat prediksi krisis perbankan berbasis Banking Sector Fragility Index di Indonesia

Hasil penelitian ini bertentangan dengan kerangka pemikiran dan hipotesis.
Tidak berpengaruhnya inflasi terhadap krisis perbankan berbasis Banking Sector Fragility Index di Indonesia, mengindikasikan nilai laju inflasi selama pengamatan tergolong rendah masih dibawah $10 \%$ dengan rata-rata tingkat inflasi sebesar 0,5140\%. Inflasi tertinggi terjadi pada triwulan ke 4 tahun 2014 sebesar $1,48 \%$, angka ini tergolong dalam inflasi rendah yang masih dibawah $10 \%$. Kendatipun begitu pengaruh inflasi terhadap krisis perbankan bersifat negatif yang menunjukkan semakin tinggi tingkat inflasi menyebabkan semakin rapuh (semakin rendah nilai BSF) kondisi bank. Inflasi yang tinggi memicu masyarakat untuk membelanjakan uangnya. Hal ini menyebabkan sebagian besar pendapatan yang dimiliki masyarakat akan digunakan untuk berkonsumsi daripada disimpan (ditabung dalam bank).

Kondisi ini menyebabkan bank kekurangan tabungan karena nasabah akan cenderung untuk melakukan pengambilan uang daripada penyimpanan uang sehingga pada akhirnya menyebabkan kondisi keuangan bank semakin buruk dengan penurunan profitabilitas. Adanya kebijakan moneter Bank Indonesia untuk mengelola tekanan harga agar laju inflasi dapat dipertahankan pada tingkat yang rendah dan stabil menjadikan pengaruh inflasi tersebut tidak berdampak buruk terhadap kondisi keuangan. Hasil penelitian konsisiten dengan penelitian Budiarti (2014) yang menyatakan inflasi tidak berpengaruh terhadap prediksi krisis dikarenakan Bank Indonesia telah menggunakan Inflation Targetting Framework (ITF) untuk penetapan target inflasi dan pengambilan kebijakan yang tepat dalam menekan angka inflasi. Salah satu keuntungan penerapan ITF adalah arah kebijakan moneter lebih mudah dipahami dan tepat sasaran. Dengan diterapkannya ITF, laju inflasi di Indonesia semakin terkendali dan 
pada saat laju inflasi tinggi peran kebijakan moneter yang diambil oleh Bank Indonesia juga meningkat.

6. Pengaruh nilai tukar sebagai alat prediksi krisis perbankan berbasis Banking Sector Fragility Index di Indonesia

Hasil penelitian ini bertentangan dengan kerangka pemikiran dan hipotesis. Tidak berpengaruhnya nilai tukar terhadap krisis perbankan karena nilai tukar berada pada pasar uang yang bersifat jangka pendek, sehingga pengaruh nilai tukar terhadap laba perusahaan ikut bersifat fluktuatif. Hasil penelitian konsisten dengan penelitian Aviliani, dkk (2015) hasil analisis korelasi, nilai tukar merupakan variabel makro yang memiliki hubungan paling lemah dengan semua indikator kinerja bank. Nilai tukar tidak berpengaruh signifikan terhadap ROA.

\section{PENUTUP}

\section{Kesimpulan}

Dari hasil analisis data antara variabel bebas dan variabel terikat diketahui hanya 6 bank dari 37 bank sampel penelitian yang dikatagorikan sehat berbasis Banking Sector Fragility Index di Indonesia dalam menjalankan usahanya yaitu PT Bank Rakyat Indonesia (Persero) Tbk, PT Bank Negara Indonesia (Persero) Tbk, PT Bank Tabungan Pensiun Nasional, PT Bank Tabungan Negara (Persero) Tbk, PT Bank OCBC NISP Tbk, PT Bank Cimb Niaga, Tbk.

Dari hasil analisis data antara variabel bebas dan variabel terikat dapat diketahui dari 37 bank sampel penelitian yang dikatagorikan tidak sehat berbasis Banking Sector Fragility Index di Indonesia dalam menjalankan usahanya dari variabel modal, ROA, ROE, NIM, BOPO, LDR, dan NPL adalah PT Bank Pundi Indonesia dan Bank JTrust Indonesia yang tergolong tidak sehat berbasis Banking Sector Fragility Index di Indonesia dalam menjalankan usahanya dari variabel modal, NIM dan LDR.
Adapun hasil analisis dari masing masing variabel bebas dan variabel terikat terhadap 37 sampel penelitian dapat disimpulkan sebagai berikut:

1. Modal tidak dapat digunakan alat sebagai prediksi krisis perbankan berbasis Banking Sector Fragility Index di Indonesia.

2. Profitabilitas dapat digunakan alat sebagai prediksi krisis perbankan berbasis Banking Sector Fragility Index di Indonesia.

3. Likuiditas dapat digunakan sebagai alat prediksi krisis perbankan berbasis Banking Sector Fragility Index di Indonesia.

4. PDB tidak dapat digunakan sebagai alat prediksi krisis perbankan berbasis Banking Sector Fragility Index di Indonesia.

5. Inflasi tidak dapat digunakan alat sebagai prediksi krisis perbankan berbasis Banking Sector Fragility Index di Indonesia.

6. Nilai tukar tidak dapat digunakan sebagai alat prediksi krisis perbankan berbasis Banking Sector Fragility Index di Indonesia.

\section{Saran}

Dengan melihat manfaat penelitian dan berdasarkan hasil penelitian sebelumnya, maka penulis dalam hal ini dapat menyampaikan beberapa saran sebagai berikut:

1. Untuk pemimipin bank sebaiknya memperhatikan faktor-faktor internal perbankan seperti profitabilitas, mengingat profitabilitas memiliki pengaruh signifikan terhadap prediksi perbankan di Indonesia. Hal ini dapat dilakukan dengan cara terus melakukan evaluasi terhadap tingkat profitabilitas yang dapat dicapai.

2. Untuk pemerintah perlu melakukan perhatian yang tinggi terhadap faktor eksternal terutama tingkat inflasi dan nilai 
tukar dan variabel lainnya yang rentan terhadap tidak stabilnya kondisi makro dan mikro ekonomi. Hal ini dapat dilakukan dengan cara terus memonitor perubahan-perubahan kedua variabel tersebut dan variabel lain yang mempengaruhi ketidakstabilan ekonomi serta mengambil tindakan antisipasi jika variabel tersebut terjadi perubahan.

3. Untuk investor perlu memperhatikan manajemen risiko dalam berinvestasi sehingga mampu menghasilkan nilai profitabilitas yang tinggi bagi pemilik saham dan perusahaan.

4. Untuk akademisi perlunya melakukan penelitian lebih lanjut dengan cara memasukan variabel lain yang juga dapat berpengaruh terhadap prediksi krisis perbankan.

\section{DAFTAR PUSTAKA}

Almilia and Herdinigtyas, Winny. 2005. Analisis Rasio CAMEL Terhadap Prediksi Kondisi Bermasalah pada Lembaga Perbankan Perioda 2000-2002. Jurnal Ekonomi Akuntansi dan Keuangan, Vol.7, (No.2): 131-14.

Aviliani, et al. 2015. "The Impact of Macroeconomic Condition on The Banks Performance in Indonesia." Buletin Ekonomi Moneter dan Perbankan 17.4 (2015): 379-402.

Bank Indonesia, 2001. "Surat Edaran Bank Indonesia Nomor 3/30/DPNP Tentang Laporan Keuangan Publikasitriwulan Dan Bulanan Bank Umum" 14 Desember 2001. http://www.bi.go.id.

2011. "Surat Edaran Bank Indonesia Nomor 13/24/DPNP Perihal Penilaian Tingkat Kesehatan Bank Umum" http://www.bi.go.id.

Baskoro, Agus. 2014. Analisis Rasio-rasio Keuangan untuk Memprediksi Financial distress Bank devisa Periode 20062011. Journal of Business and Banking, Vol. 4 No.1, 105-116.
Budiarti, 2014. Identifikasi Modal, Profitabilitas, Likuiditas, Pdb, Inflasi Dan Nilai Tukar Sebagai Prediksi Krisis Perbankan Di Indonesia. Jurnal Mahasiswa Teknologi Pendidikan. Jurnal IImu Manajemen Vol 2 Nomor 4.

Budimanra, 2008. Corporate Social Responsibility Alternative Bagi Pembangunan Indonesia Centre For Substanbility Development (ICSD) Jakarta.

Bruinshoofd, et al. 2008. Banking Sector Fragility and the Transmission of Currency Crises. research article doi 10.1007/s11079-008-9078-4

Department of Macroeconomics Research, Rabobank Nederland, Utrecht, The Netherlands.

Caprio and klingebiel, 1996. Bank Insolvencies Cross-Country Experience. The World Bank Policy Research Working Paper No 1620 Juli 1996.

Cihak, M., dan Poghosyan, T. 2009. Distress in European banks: An analysis based on a new data set. IMF Working Paper.

Domaç, I. and Peria, M.S.M., 2000. Banking Crises And Exchange Rate Regimes: Is There A Link? Journal of International Economics, 61(1), pp.41-72.

Degryse, et al., 2013 Determinants of Banking System Fragility A Regional Perspective Working Paper SerieS NO 156 / july 2013.

Gunsel, Nil, 2007. Financial Ratios and the Probabilistic Prediction of Bank Failure in North Cyprus. European Journal of Scientific Research Vol.18 No.2 (2007), pp.191-200

Himawan, Adhitya. "Riset Info Bank: 65 bank berpredikat sangat bagus" 3 Juli 2015. http://keuangan.kontan.co.id.

Https://www.bps.go.id

Https://www.idx.co.id

Kajian Stabilitas Keuangan Bank Indonesia, 2003. http://www.bi.go.id. 
Kanya Prasidh, Diana dan Tri, Setyo Wahyudi, 2015. Dampak Nilai Tukar Dan RiskBased Bank Rating Terhadap Prediksi Kondisi Perbankan Indonesia (Studi Pada Bank Umum Swasta Nasional Go Public Tahun 2009-2013) Universitas Brawijaya. Malang.

Krisnawati, 2014. Analisis Faktor Penentu Profitabilitas Bank di Indonesia Dengan Metode Risk Based Bank Rating (Studi Pada Bank-Bank Umum Go Public di Indonesia Periode 2008-2013). Universitas Diponegoro.

Kibritcioglu, 2002 Excessive Risk Talking, Banking Sector Fragility And Banking Crises

http://www.business.uiuc.edu/Working _Papers/papers/02-0114.pdf 2003 Monitoring Banking Sector Fragility Bankinglntroduction Management The Arab Bank Review Vol. 5, No. 2 October 2003 pp 51-66

LPS, 2014. "Analisis Stabilitas dan Sistem Perbankan Triwulan I 2014 Likuiditas Perbankan Permasalahan, Risiko dan Kebijakan" https://www.Ips.go.id , 2015. "Perekonomian dan Perbankan Mei 2015" https://www.Ips.go.id
Mulyaningrum, Penny. 2008. Analisis Rasio Keuangan Sebagai Indikator Prediksi Kebangkrutan Bank di Indonesia. Thesis S2 Magister Akuntansi Universitas Diponegoro

OECD Economic Surveys Indonesia, 2015. www.oecd.org/eco/surveys/economicsurveyindonesia

Oktavilia, Shanty 2008. Deteksi Dini Krisis Perbankan Indonesia: Identifikasi Variabel Makro Dengan Model Logit, JEJAK, Volume 1, Nomor 1, September, 2008 Fakutas Ekonomi Universitas Negeri Semarang

Rakhmawati dan Hermana, 2005, Evaluasi Kinerja Keuangan Bank dalam Kerangka Arsitektur Perbankan Indonesian Perbandingan Kredit Bermasalah, Kecukupan Modal, Likuiditas Dan Rentabilitas. In Proceeding, Seminar Nasional Pesat 2005. Universitas Gunadarma.

Simorangkir, Iskandar dan Suseno. 2004. Sistem dan Kebijakan Nilai Tukar, Seri Kebanksentralan No 12. Jakarta: Pusat Pendidikan dan Studi Kebanksentralan Bank Indonesia (PPSK BI). 